\title{
Jean Berrett
}

\author{
In This Parched Land, Lunacy and Love: A \\ Review of Khamsin, By Moshe Dor
}

"GLEAMING SANDS of gold fell in bewitching folds toward the sea . . . a vast haven between blue and green . . . Camel caravans passed, bells clanging on their swaying necks. . . Beyond . . . stretched a desert of white sand. Out there stood a solitary lamp post like a lighthouse. In the long summer evenings the lamp cast long shadows on the sand. Children would sit around it, telling stories."

From that lovely remembrance and evocation of the lay of earth and sky on the Mediterranean coast and the open and impressionable topography of a child's mind, the acclaimed Israeli poet, Moshe Dor, author of some thirty volumes of poetry and winner of Israel's top literary award, the Bialik Prize, proceeds in Khamsin with a series of meditations on his coming of age as an artist and a man in Israel. The memoirs section, "This Parched Land," is followed by a selection of poems collected under the rubric "More Distant than Lunacy, than Love?" This memoir/poetry collection was translated from the original Hebrew by Pulitzer Prize recipient Henry Taylor and fourteen other authors, including Myra Sklarew and Barbara Goldberg.

Dor's father was a Zionist-socialist pioneer, who grew up under Romanov despotism and who made "aliya" by stealthily crossing the Soviet border to migrate to Israel. Dor was born in 1932 and grew up in the Workers' Quarter of Tel Aviv as a precocious book-hungry child who was painfully handicapped by stuttering and who in spite of a desperate longing to fight in the 1948 War of Liberation was deemed too young to join in, a lucky circumstance for we who were spared the misfortune of being denied his poetry. After the war, Dor joined with other writers to form Likrat, the anti-Soviet, anti-bureaucratic literary vanguard in Jerusalem of the early $50 \mathrm{~s}$. About the anti-Soviet stance of Likrat in an Israel where Stalinist "socialist realism" was still a formidable presence, Dor simply says: "Stalin's Soviet Union disgusted me."

Three Continents Press. Colorado Springs, CO 80937, 1994. 
He tells us that in response to Likrat, "The representatives of accredited, kosher Stalinism, spokespersons for the communist slaughterhouse, banged their blackened pots and polished their dull knives." Likrat was also dead set against the literary status quo in Israel, striving "to open windows to Western literature, then a sealed book to most of the younger writers." When a selection of Whitman poems was published in Hebrew, Dor recalls the young writers reading rhapsodically from the new translation:

Poets to come! orators, singers, musicians to come!

Not to-day is to justify me and answer what I am for,

But you, a new brood, native, athletic, continental, greater than before known,

Arouse! for you must justify me . . .

Dor tells us that all of them felt Whitman was speaking directly to them.

While, since those youthful times, he has travelled widely and resided in other lands, Dor speaks again and again of his Israeli motherland, in longing and nostalgia, in praise and disappointment. In a memoir chapter called "Star Particles," he says:

The motherland is not a name, an ideology, a naked thought. It appears in a mosaic of small living tangible images. The Land of Israel-it glows in my blood, flesh, and nerves. The motherland is the country in my soul, whether asleep or awake, and in all the dark and shining labyrinths of time.

Dor laments in his essay "To the Sun" the terrible changes which those labyrinths of time have wrought on the motherland:

The little houses have disappeared. The bells on the camels' long necks are silent. The horizon is hidden behind tall buildings. The sycamores have been cut down. The air is polluted and the water of the Yarkon is tainted with effluence. My Tel Aviv is hiding . . . and I seek her, in love and despair. 
In the beautiful poem "Camels," he speaks of the land itself bemoaning its own desecration. Here, the poet says that even the sand protests its ravishment by industrialization and the monstrous city grown up at its side. He says the sand now conspires with the moon to reclaim the past. "The God of Sand takes it down / in his private notebook ... / And like a secret agent, a faint moon / sneaks up and peeps / out . . " How beautifully imagination and memory collude in this piece to bring back something lost-an immense expanse of clean sand which climbs "invisible ladders of light," as "broad soft hooves" of ". . . phantom camels traverse / pillars and molds."

In a poem called "In the Absence of a Motherland," the poet says that

Without a spiritual motherland

it is the Israel of blood the soul loves. . .

In the absence of a spiritual people

the beloved is Israel of flesh and blood...

Without a language of the spirit

Israel of blood is multiply loved . . .

In this poem, the religious/spiritual imperative, the old God-direction has fled, and the land becomes only as it is perceived and loved by the "flesh and blood," the senses. Without the burden of spiritual definitions and justifications, Israel of the flesh and blood becomes a starkly beautiful place where

a dark child rends the sea,

... the acacia hedge bathes in gold

and when noontide slumbers,

on the glass of the horizon, the bird

of your heart knocks softly to be admitted.

In fact, the sensuous present counterposes throughout the poems in Khamsin-against politics and business, against memory and changes in time, against death. The notion of the senses or sensuality supplant- 
ing the politics of war in the motherland is very explicitly stated in "Citizen of the World."

First we talked about war and peace and how power corrupts and what's good for the nation. Then Baba washed her hair. Suddenly I knew as she dried it, as the hair drier whooshed, that I don't give a fig for politics, but only that ease that lets me watch Baba drying her hair, as if time had no measure and she was the world's sole custodian, no borders, no customs officials, and I'm there, sheltered in the shadow of her hair, in the thick of it.

And yet Dor's renunciation of world affairs in favor of a return to the sensual is also an attempt to return to a belief in something beyond humanity's endless attempts to control and conquer. In "Alien Light," he says:

Touch me. I want to believe again

in implacable processes, the just

verdict of history, melting icecaps, the spiraling stars.

This beautiful little poem utters a wish for some kind of primal faith engendered by the simple act of touching. The hope for belief in "implacable processes" is a hope to believe again in that which is indefinable and uncontrollable. Faith in the "just verdict of history" may be a last wish that the wrongs to the Jews in this terrible century be righted. The "melting / icecaps, the spiraling stars" suggest other implacable processes for belief, God perhaps, or even death, the most implacable of all.

The title of Part Two of Khamsin, "More Distant Than Lunacy, Than Love?" is taken from a touching poem written to the poet's father, whose personal dream was to become a mining engineer after settling in Israel. In this poem, Dor describes how his father ". . . came / to a good land . . . out of whose hills / thou mayest dig brass." The biblical 
sound of "mayest" in this first stanza gives the story of his father's migration to Israel a tone of biblical allegory. About his father's lost dream of becoming a mining engineer, the poet asks "What did he hope to find . . . ?" He then calls himself, the "alien" son, an Icarus who ". . . sinks into the abyss / on molten wings of wax, shattering / the dream of redemption." What this dream-shattering tells of the fatherson relationship is not specified in the poem, but obviously some great disappointment or disconnection lay like an impassable valley between them. Nevertheless, in spite of any disconnection between them, in the poem "Father," Dor expresses an utterly genuine compassion:

For years my father was confined to a desk job, the echo of pickaxes, of rustling water, growing faint as though muffled by cottonwool. His brown eyes stared dully at walls where frustration flickered in the lantern light, his inner ear hearing the sweet sound of pickaxes striking veins of coal. Returning home late at night, my father felt pits gape underfoot, like the emptiness beneath a mountain's ribs.

After this luminous, resonant and sad commentary, the poet asks

And what of your alien son yearning to mine deepest space, to chart galaxies more distant than lunacy, than love?

Here we have the poet's attempt to understand the strange separation between father and son, their differences, the way their "mining" was diametrically opposed, in direction, demeanor and intent. In the last stanza, Dor speaks of how since death his "dustfather"

... practices a new

kind of mine engineering, perhaps

in a chosen land. Or one that is not. 
These haunting final words summon the whole tradition of Judeo-Christian belief, with the abiding query of whether or not there is a chosen land, or a life after death. The choice of words and their spacing on the page is so quietly and exquisitely balanced here that you can almost see the scale teetering with the weights of the two alternatives. And the final five words, set apart as a separate statement, resound like some terribly possible final judgment.

One of the most intriguing and compelling characteristics of Dor's poetry in Khamsin is the way in which he keeps returning to ultimate unanswerable questions. "And what shall I do? What shall I do?" the poet asks in "Ecology." "And what of us? Where are we, where do we set our faces?" he asks in "Navigation." "What more is left? . . Is there time? Is it still possible to plead for mercy?" the poet asks in "December." "How shall I ever find peace . . . ?" he asks in "Father." Dor asks these questions knowing they cannot be answered, knowing nevertheless they must be asked. The questions are a crying out from the human condition, a protest and invocation, voiced plainly and incorrigibly, as if to God above.

In "Twilight," Dor moves into a quietly lingering mood as he speaks of aging as a "twilight" that "bandages our eyes, / a blindfold before the last / order ..." One thinks of the blindfolds dressing the eyes of those about to be executed. The poet explains that in the time of twilight ". . . a silent / world totters and slumps, / its shape altered." The shape the world had in our youth, so strong and clear in meaning, totters and slumps as we grow older. The extraordinary and undivined purport of this poem comes in the last two lines when the poet says directly to the beloved "You" of the second stanza:

Please now, hold my hand gently, with great care.

This final plea to be gentle and kind to him in these "twilight" hoursa plea so direct and simple, so full of a childlike need and trust, swings the poem swiftly from a tempered meditation to an aching human cry from the heart. This poem moves in so close at the end that the reader must tremble. 
In the essay "Kaestner's Footsteps," which closes the memoir section, Dor, looking back on his life, calls his poetry "bridges, stretched to the shape of my native landscape." He tells how his journeys have finally led him to a place where

... the scope of my horizons does not expand but retracts . . . Distant lands retreat before the Land of Israel. Jerusalem retreats before Tel Aviv ... The grass becomes more grassy in its shrinking spot of soil . . My circuit has come to its close. No longer must I travel even to the outskirts of a metropolis. It is enough to go from one street to another. From one neighbor's house, with its small plot of land, to the next.

A poignant reminder of how, as we gradually move closer to death, landscapes retract and life returns us to whatever motherland exists, not out there in the world, but deep inside ourselves.

In the very last poem in Khamsin, Dor names love as his final interpreter.

Love, be a white flame

between me and the bloodless

ghosts, and you be the one

to close my eyes when I

am drawn into night's fold.

In this very short piece, titled "For Those Who Would Reprove Me for My Foolishness," love, physical or spiritual or in any understanding of it, is the poet's own final reproof against the "bloodless ghosts." The ghosts could be the poet's living critics who, being without that blooddriven love, would censure his reiterative celebration and veneration of the life of the senses, or they could be the already dead who augur his own ultimate loss of the rushing blood that carries those senses. In any case, in the end it is some kind of primeval and powerful sense of "love" that Moshe Dor, disavowing any fear of those who call it "foolish," names as the protector, comforter and giver of meaning to his existence. 